\title{
Mapping Porosity Values on Coast of Sampang District Using Satellite Image Data
}

\author{
Dian Purnamawati Solin ${ }^{1}$, Hendrata Wibisana, Siti Zainab \\ Civil Engineering Department \\ Universitas Pembangunan Nasional "Veteran" Jawa Timur \\ Surabaya, Indonesia \\ 1diansolin04@gmail.com
}

\begin{abstract}
Porosity soil is well known as soil properties and an indicator of the quality of soil. Applying porosity test in coastland area of Sampang District is highly needed, considering that the livelihoods of the people in Sampang are mostly farmers and also the development of village has recently grown rapidly. In this study, the mathematical model of porosity would be obtained by using the data of surface reflectance Aqua Modis. Using the Aqua Modis can provide an overview of porosity value in all over Madura Island that can be used as reference and as actual data in designing structures (road pavement) in the future. The porosity value were processed with three bands that have wavelength $445 \mathrm{~mm}, 530$ $\mathrm{mm}$ and $665 \mathrm{~mm}$. The experimental result shows that most of soil type on coastland area of Sampang is fine sand. The most optimum regression from the mathematical model was exponential model with regression $=0.2911$. This result showed that applying global mapping with satellite image data was able to provide an overview of porosity value in Sampang District. This data plays an important role in the future for increasing the quality of soil and also as a reference for construction design.
\end{abstract}

Keywords—porosity, satelite imagery, mapping, Sampang.

\section{INTRODUCTION}

Soil presents with unique properties and wide variety types. The unique of this soil makes soil become different from one another through the physical properties, behavior and etc. As it is known, soils are consists of pores, water and solid granules (minerals and organic material) [1]. These three part of soils play an important role and indicate the quality of soil. The good soil would hold the water and air for the needs of plants and enough space for the root penetration.

Porosity is defined as the ratio between pore volume and total soil volume [1]. It means that porosity is strongly influenced by packing density, breadth of particle size distribution, and shape of particles. Ideally, the range value of porosity soil is $0.26-0.48$. It depends on the type of the soils and the packing. A material with more irregular in shape will have higher value of porosity, otherwise solid material will have smaller value. This is caused by soil particles that bind each other and fill the gaps of pores soil. The porosity value in this case can be less than 0.3 and nearly 0.00 [2].
In general, there are two type of porosity in soils, those are: macro-pores and micro-pores [3]. Macro-pores were formed with large diameter of pore, usually more than 0.08 $\mathrm{mm}$. In a heavy rain season, the soil will easily getting saturated. This pores is also called as aeration porosity or non-capillary porosity. Micro-pores, formed with good pores, the pores can hold and directly store the water. The water in soil will not disappear even in the presence of gravity. The diameter of micro-pores usually smaller than $0.08 \mathrm{~mm}$. It is often called as capillary porosity.

The aims of this study are to map and find the algorithm of mathematical models in the coastland area of Sampang District. There are four algorithm mathematic models that have been used in this research. Those are: linear, exponential, logarithm and power model. The purpose of using these four models is to determine the math correlation and regression of porosity and surface reflectance Aqua Modis. By using the correlation analysis of reflectance values or RGB (Red-Green-Blue) wavelength from sensors on satellite, the porosity value can be mapped well [4] [5].

\section{MATERIALS AND MEthodS}

\section{A. Study Area}

Sampang is located on Madura Island. It covers an area of $1233,1 \mathrm{~km}^{2}$. It lies between $7^{\circ} 12^{\prime} 35.60^{\prime \prime}$ to $7^{\circ} 12^{\prime} 53.24^{\prime \prime}$ of the southern latitude and $113^{\circ} 13^{\prime} 58.80^{\prime \prime}$ to $113^{\circ} 19^{\prime} 0.48^{\prime \prime}$ eastern longitude, around the equator.

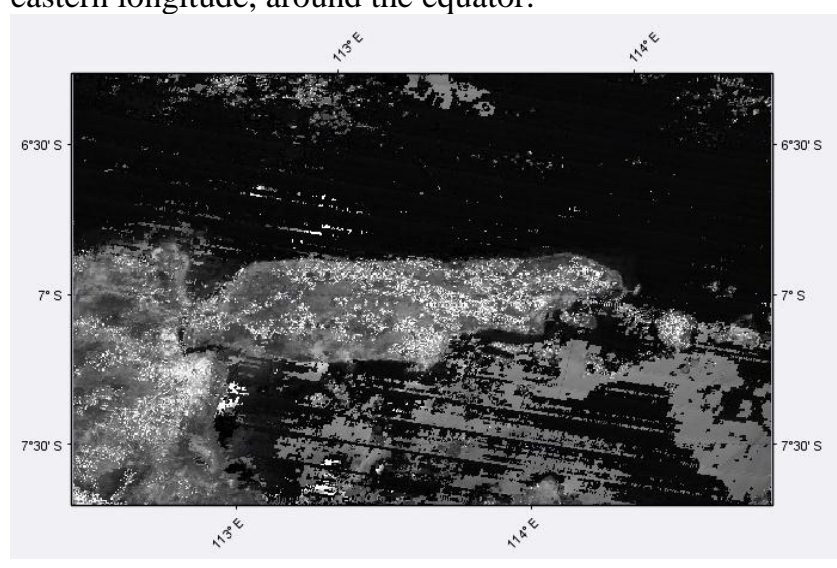

Fig 1. Research Location 
In Sampang, the rainy season starts from October to March with average $95.8 \mathrm{~mm}$ of rainfall in a month and dry season starts from April to September with average 95.8 $\mathrm{mm}$ of rainfall in a year [6]. It can be said that the rainfall distribution is good.

As described in introduction, most of Sampang area is agricultural area. Moreover, the coastal areas are also used as plantation area. Therefore, the soil analysis has to be taken on priority to determine the quality of soil [7].

\section{B. Research Methodology}

Before taking the samples from Sampang, a survey should be done first. Soils were collected with ten coordinates, these coordinate were chosen using a map. Most of these coordinate represent the plantation area and some of it represent road area. When taking the samples, the top of sample was removed to avoid the disturbed soil. The lengths of sample are around $15-20 \mathrm{~cm}$ with $6.5 \mathrm{~cm}$ diameter [8] [9].

All these samples were analyzed using standard procedures for identifying the porosity and bulk density in laboratory [5]. In the first step, the samples should be weighed. After weighing, the samples are soaked in the water within 7 days in $1 \mathrm{~cm}$ height of water. In these 7 days, the water should be considered and checked day by day to make sure that the water does not run out. If necessary the water can be added if there is a significant water reduction during the soaking. Thereafter, the samples should be taken out and weighed. The samples weight must be recorded properly. After weighing the soil samples were separated from tube by using extruder. The samples were put in oven for \pm 24 hours. After \pm 24 hours the samples should be weighed again. Briefly, the samples are weighed on two condition, before soaking and after soaking. From all this series process, in the end the porosity value can be determined by using the equation bellowed [1]:

$$
\mathrm{n}=\frac{\mathrm{Vv}}{\mathrm{V}}
$$

Where:

$$
\begin{array}{ll}
\mathrm{n} & =\text { Porosity value } \\
\mathrm{Vv} & =\text { Pore volume } \\
\mathrm{V} & =\text { Total soil volume }
\end{array}
$$

Since there is a unique correlation and relation between porosity and bulk density value, in this research, the bulk density of soil is also determined. There are a lot researcher said that the porosity value cannot be separated with bulk density value [3]. To determine the bulk density value, the equation bellowed was used [1]:

$$
\mathrm{BD}=\frac{\text { Dry Soil Weight }}{\mathrm{V}}
$$

Where:

$$
\begin{array}{ll}
\mathrm{BD} & =\text { Bulk density } \\
\mathrm{V} & =\text { Total Soil Volume }
\end{array}
$$

\section{Algorithm Mathematic Models}

In this research, the algorithm mathematic models were used. There are four mathematic models that used in this research, these four models are commonly used in remote sensing research. These four models are: linear, exponential, power and logarithm. From these models, the result of porosity are analyzed using the method of least-squares regression and the correlation coefficient $\left(\mathrm{R}^{2}\right)$ was determined.

\section{RESULT AND DISCUSSION}

\section{A. Porosity And Soil Classification}

Following a soil porosity test, porosity values of 10 coordinate samples were obtained (Table 1.). The table shows the range of porosity is 0.223-0.419. By using correlation between porosity value and classification soil and visible observation, the porosity can be related to soil classification (Table 2.).

\section{TABLE I. POROSITY VALUE}

\begin{tabular}{|c|c|c|}
\hline \multicolumn{2}{|c|}{ Coordinate } & \multirow{2}{*}{$\begin{array}{c}\text { Porosity } \\
\text { (n) }\end{array}$} \\
\cline { 1 - 2 }$x$ & $y$ & 0.277 \\
\hline-7.20989 & 113.233 & 0.310 \\
\hline-7.21157 & 113.2327 & 0.419 \\
\hline-7.21106 & 113.2328 & 0.298 \\
\hline-7.211665 & 113.3177 & 0.340 \\
\hline-7.21628 & 113.3176 & 0.257 \\
\hline-7.21603 & 113.3176 & 0.332 \\
\hline-7.2157 & 113.3175 & 0.250 \\
\hline-7.21525 & 113.3175 & 0.304 \\
\hline-7.21469 & 113.3175 & 0.223 \\
\hline-7.21479 & 113.3168 & \\
\hline
\end{tabular}

TABLE II. CORRELATION BETWEEN POROSITY AND SOIL CLASSIFICATION

\begin{tabular}{|r|l|}
\hline Porosity (n) & \multicolumn{1}{|c|}{ Soil Classification } \\
\hline 0.277 & Sandy clay \\
\hline 0.310 & Fine sands \\
\hline 0.419 & Fine sands \\
\hline 0.298 & Fine sands \\
\hline 0.340 & Fine sands \\
\hline 0.257 & Sandy clay \\
\hline 0.332 & Fine sands \\
\hline 0.250 & Silty clay \\
\hline 0.304 & Fine sands \\
\hline 0.223 & Silty clay \\
\hline & \\
\hline
\end{tabular}

The result shows silty clay tend to have lower porosity comparing to fine sand. High porosity value was observed in find sand with range between 0.298-0.419. From the result, it is seen that there is a linear relation between 
porosity value and particle size, as it is known that particle size of sand is tend to be bigger than silt and clay. M. Irham Nurdiyanto reported that the porosity values have the strong linear correlation to particle size [10] [11]. J.R Nimmo, reported that porosity depends on particle size distribution [2]. As can be seen, that most of the type of soil in coastland area is fine sand. The fine sand type shows the characters of coastal area which is formed by sediments and affected by the sea.

\section{B. Porosity and Bulk Density}

It was observed that there is a relationship between porosity and bulk density (see Fig.2) [3] [11]. By using correlation and regression analysis, the relation between porosity and bulk density is shown as a linear line $\mathrm{y}=$ $1.1172 \mathrm{x}+2.0834$ with $\mathrm{x}$ is porosity and $\mathrm{y}$ is bulk density.

TABLE III. BULK DENSITY AND POROSITY VALUE

\begin{tabular}{|r|r|c|}
\hline \multicolumn{1}{|l|}{ Sample } & \multicolumn{1}{|c|}{ Porosity(n) } & $\begin{array}{c}\text { Bulk } \\
\text { Density } \\
\text { (gr/cm3) }\end{array}$ \\
\hline 1 & 0.276643297 & 1.774 \\
\hline 2 & 0.310431246 & 1.735 \\
\hline 3 & 0.419089605 & 1.619 \\
\hline 4 & 0.298116719 & 1.749 \\
\hline 5 & 0.340241447 & 1.700 \\
\hline 6 & 0.256592668 & 1.800 \\
\hline 7 & 0.33212606 & 1.709 \\
\hline 8 & 0.249662286 & 1.806 \\
\hline 9 & 0.304445255 & 1.742 \\
\hline 10 & 0.223081726 & 1.835 \\
\hline
\end{tabular}

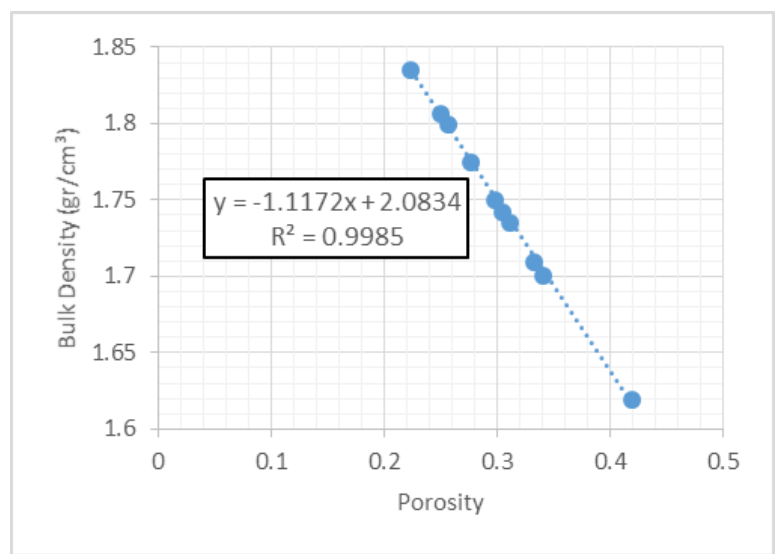

Fig. 2. Variation of Porosity with Bulk Density of Soil Samples

The relation between these two parameter shows a tendency negative with high regression $\mathrm{R}^{2}=99.85 \%$ which means the higher porosity value, the lower bulk density value. Joel Kakaire reported that between two properties of soil (porosity and bulk density value) were found a strong negative correlation. $(\mathrm{r}=0.9149)$ [12]. Johandre Arpindra
Surya also reported that between porosity and bulk density has a negative correlation [10] [14]. This linear mathematical model is acceptable because the regression value is nearly 1 .

\section{Algorithm Mathematic Model}

The algorithm mathematic model calculation for each reflectance from Aqua Modis data to porosity values were obtained using correlation and regression analysis. This result show the relationship between mathematic models and data accuracy. Using band 1 reflectance, the algorithm mathematic models (linear, exponential, logarithm and power) were shown in Table 3.

TABLE IV. ALGORITHM OF MATHEMATIC MODELS FOR BAND 1 AQUA MODIS

\begin{tabular}{|r|l|l|r|}
\hline No & \multicolumn{1}{|c|}{ Model } & Math Correlation & \multicolumn{1}{c|}{ Regression } \\
\hline 1 & Linear & $\mathrm{y}=-1.2558 \mathrm{x}+0.3707$ & 0.2837 \\
\hline 2 & Logarithm & $\mathrm{y}=-0.113 \ln (\mathrm{x})-0.0165$ & 0.272 \\
\hline 3 & Exponential & $\mathrm{y}=0.3938 \mathrm{e}^{-4.877 \mathrm{x}}$ & 0.2911 \\
\hline 4 & Power & $\mathrm{y}=0.0871 \mathrm{x}^{-0.44}$ & 0.2815 \\
\hline
\end{tabular}

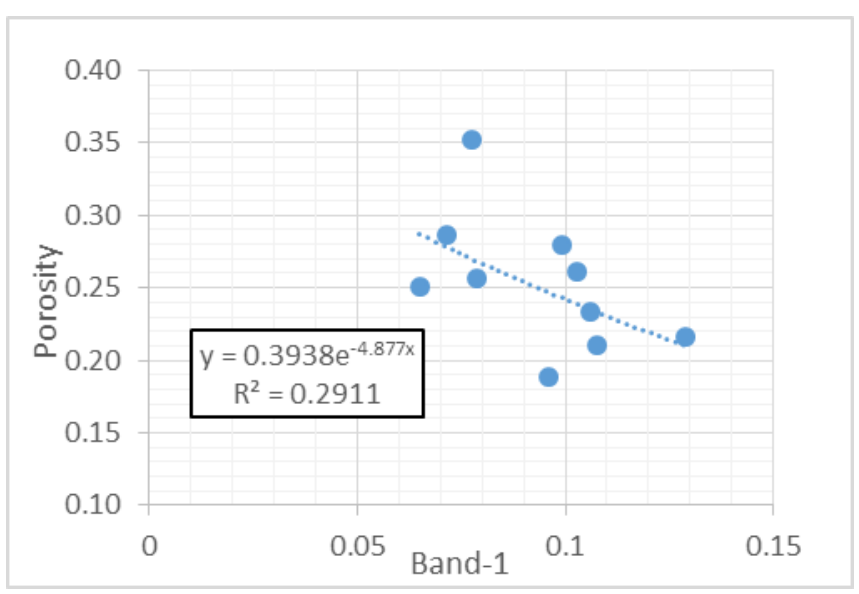

Fig. 3. Exponential Mathematic Model of Band 1

As shown in Table 3 and Figure 3, the highest regression value was obtained by using exponential model witht regression $\mathrm{R}^{2}=0.2911$. It means that there is $29.11 \%$ of porosity value which can present in band 1 Aqua Modis reflectance data. Comparing to linear model the difference is really small around 0.0074 .

For band 2 reflectance, the highest regression value was same as band 1. Exponential model got the high regression with $\mathrm{R}^{2}=0.0966$. Both of band 1 and band 2 for linear and logarithm mathematic model show the tendency negative.

In table $\mathrm{v}$, the highest regression value was obtained by using linear model with $\mathrm{R}^{2}=0.0026$. Since the regression value in band 3 reflectance is too small if comparing to band 1 and 2. It means that using band 3 of reflectance Aqua Modis with wavelength $445 \mathrm{~mm}$ is not suitable for mapping the porosity. From all the linear and logarithm mathematic model for band 1, 2 and 3 shows tendency negative which 
means the higher porosity value, the lower wavelength reflectance.

TABLE V. ALGORITHM OF MATHEMATIC MODELS FOR BAND 2 AQUA MODIS

\begin{tabular}{|r|l|l|c|}
\hline No & \multicolumn{1}{|c|}{ Model } & \multicolumn{1}{c|}{ Math Correlation } & Regression \\
\hline 1 & Linear & $\mathrm{y}=-0.1167 \mathrm{x}+0.2685$ & $\mathrm{R}^{2}=0.0795$ \\
\hline 2 & Logarithm & $\mathrm{y}=-0.008 \ln (\mathrm{x})+0.2316$ & $\mathrm{R}^{2}=0.0546$ \\
\hline 3 & Exponential & $\mathrm{y}=0.2662 \mathrm{e}^{-0.493 \mathrm{x}}$ & $\mathrm{R}^{2}=0.0966$ \\
\hline 4 & Power & $\mathrm{y}=0.2265 \mathrm{x}^{-0.038}$ & $\mathrm{R}^{2}=0.0747$ \\
\hline
\end{tabular}

TABLE VI. ALGORITHM OF MATHEMATIC MODELS FOR BAND 3 AQUA MODIS

\begin{tabular}{|c|l|l|l|}
\hline No & \multicolumn{1}{|c|}{ Model } & \multicolumn{1}{|c|}{ Math Correlation } & Regression \\
\hline 1 & Linear & $\mathrm{y}=-0.2914 \mathrm{x}+0.269$ & $\mathrm{R}^{2}=0.0026$ \\
\hline 2 & Logarithm & $\mathrm{y}=-0.01 \ln (\mathrm{x})+0.2249$ & $\mathrm{R}^{2}=0.0011$ \\
\hline 3 & Exponential & $\mathrm{y}=0.2544 \mathrm{e}^{-0.343 \mathrm{x}}$ & $\mathrm{R}^{2}=0.0002$ \\
\hline 4 & Power & $\mathrm{y}=0.2487 \mathrm{x}^{-0.002}$ & $\mathrm{R}^{2}=2 \mathrm{E}-06$ \\
\hline
\end{tabular}

\section{Mapping the Porosity Value}

As can be seen in algorithm mathematic model, band 1 of Aqua Modis data shows the highest regression comparing to band 2 and 3. Based on the values that have been obtained, the algorithm mathematic model of porosity soil on coastland Sampang can be represented by band 1 with exponential mathematic model. The mapping result using Seadas software was presented in Figure 3. From this figure, band 1 with exponential model was able represent $28.37 \%$ of porosity values in an overview of Sampang district.

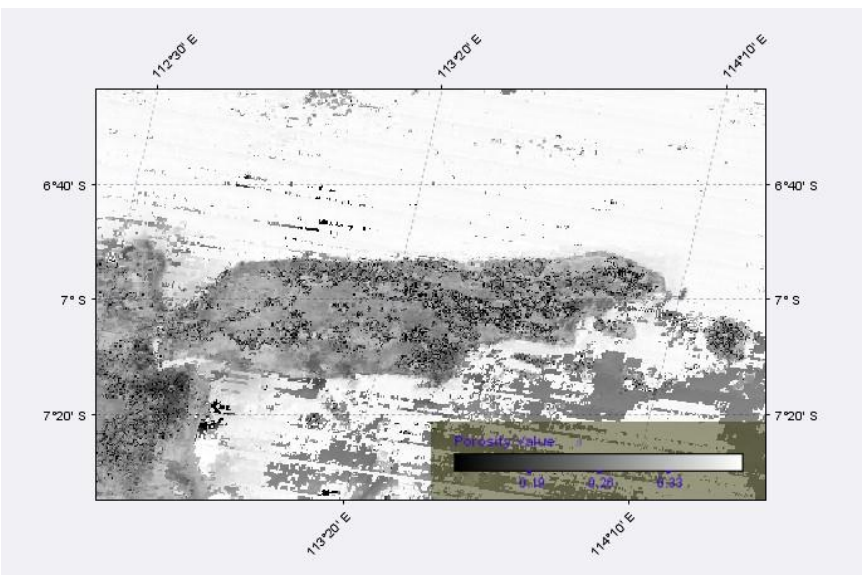

Fig. 4. Thematic Map of Porosity Soil in Sampang District Bat Based on Aqua Modis Satellite Image

\section{CONCLUSION}

Based on porosity result from laboratory, the regression value of algorithm mathematical model and application of
Aqua Modis reflectance in mapping the porosity this study can be conclude as following bellowed:

1. Most of soil type on coastland area in Sampang District is fine sand. The type of this soil might be formed by the sediment in coastland area. This type of soil is not good if used for agricultural area.

2. The highest regression was represented by exponential mathematic model using band 1 data with wavelength $665 \mathrm{~mm}$. This regression is acceptable although it just presented $29.11 \%$ of porosity value in an overview of porosity mapping in Sampang District. Comparing to band 2 and 3, the wavelength of band 1 is the largest one. It mean there is a negative relation between porosity value and wavelength reflectance Aqua Modis data.

3. Mapping porosity value using reflectance data of Aqua Modis is able in presenting an overview of porosity value of Sampang District. In the future this data can be used as reference for increasing the quality of soil and also for designing in construction field.

\section{ACKNOWLEDGMENT}

Authors kindly acknowledge the support of Lembaga Penelitian dan Pengabdian Masyarakat (LPPM) UPN Veteran Jawa Timur for the financial support in accomplishing this research. Authors would also acknowledge the civil laboratory UPN Veteran Surabaya for supporting authors in doing porosity laboratory test and for all the student who involved in our research.

\section{REFERENCES}

[1] M. D. Bradja, "Soil Mechanics", The University of Texas at El Paso, 1993.

[2] J.R Nimmo, "Porosity and Pore Size Distribution", in Encyclopedia of Soils in the Environment, London, Elsevier, v.3 pp 295-303, 2004

[3] R. Abdelaali, et al, "Porosity, Permeability and Bulk Density of Rocks and Their Relationship on Laboratory Measurement", in Revista Romance de Materiale, vol.44, Morocco, 2014

[4] S. Reis, "Analyzing Land Use/Land Cover Changes Using Remote Sensing and GIS in Rize, North-East Turkey", in Sensors, pp 61886202, 2008.

[5] G. Kaplan, U. Avdan, "Mapping and Monitoring Wetlands Using Sentinel-2 Satellite Imagery", in ISPRS Annals of the Photogrammetry, Remote Sensing and Spatial Information Sciences, Turkey, vol. IV, pp 271-277, 2017

[6] H. Heri, "Kabupaten Sampang dalam Angka 2017", Badan Pusat Statistik Kabupaten Sampang, Sampang, 2017.

[7] P. Marcello, V. Nadia, "Soil Porosity as an Indicator of Soil Health", Istituto Sperimentale per lo Studio e la Difesa del Suolo Piazza M, pp 259-286, 2006

[8] P. Haluschak, "Laboratory Methods of Soil Analysis", CanadaManitoba Soil Survey, 2006.

[9] W. W. Wessel, C. Simone, et al, "Porosity Testing Methods for the Quality Assessment of Selective Laser Melted Parts", in CIRP Annals-Manufacturing Technology, vol. 65, 2016

[10] N. M. Irham, Y. Meida, W. Sugeng, "Pengaruh Ukuran Butir terhadap Porositas dan Permeabilitas Pada Batu Pasit", in Berkala Fisika, Indonesia, vol.9 no. 4, pp 191-195, 2006.

[11] J. T Filho and Tessier Daniel, "Characterization of Soil Structure and Porosity under Long-Term Conventional Tillage and No-Tillage Systems, 2009. 
[12] K. Joel, G.L Makokha, M. Majaliwa and et al, "Effects of Mulching on Soil Hydro-Physical Properties in Kibaale Sub-catchment, Sount Central Uganda, in Applied Ecology and Environmental Sciences, vol. 3 no. 5 pp $127-133,2015$
[13] R. Pravin, Chaudari, V. Dodha Ahire and et al, "Soil Bulk Density as related to Soil Texture, Organic Matter Content and Available Total Nutrients of Coimbatore Soil, in International Journal of Scientific and Research Publication, vol.3, February 2003 